\title{
Rural-Urban Migration of the Iban of Sarawak and Changes in Long-house Communities
}

\author{
SODA Ryoji \\ Research Center for Regional Geography, \\ Hiroshima University, Higashi-Hiroshima 739-8522, Japan
}

\begin{abstract}
The Iban of Sarawak, Malaysia, who are well known as typical long-house dwellers, have attracted scholarly attention because of their frequent migration related to their custom such as shifting cultivation and "headhunting." This paper examines a new trend of the Iban's rural-urban migration and its impact on the long-house community. Recent economic development in Sarawak has provided Iban males with stabler jobs, which enabled them to sojourn longer in urban areas. This has resulted in the increase in rural-urban migration accompanied by wives and children. While more females have been leaving the long-house to follow their husbands, Iban villages experienced change in subsistence activities, such as the increase in wet paddy cultivation, the shrinkage of the average planted acreage, and the aging of the farming population. The out-migration of the younger generations and the decline in agricultural activities gave rise to the tendency of the extinction of family line and the bonds between families, which are reflected in the degradation of the long-house community.
\end{abstract}

Key words: Iban, long-house community, occupation, rural-urban migration, female outmigration

\section{Introduction}

\section{Research objectives}

In the so-called Third World countries, internal migration studies contain a core of arguments on rural-urban relations. Third World countries appear to be following their own course of urbanization and change in population composition, which is different from the process once observed in developed capitalist countries. As previous studies have frequently pointed out, a consequence of urbanization and migration in the Third World has been that multifarious job opportunities absorbed a great influx of labor from rural areas (e.g. Armstrong and McGee 1985: 13).

Recent studies have demonstrated great concern about not only the one-way flow of labor but also circulatory migration and its effect on rural communities (e.g. Prothero and Chapman 1985), the relation between migration trends and changing household composition, and the increase of female labor migration (e.g. Fawcett et al. 1984). This means that, while the previous rural-urban migration studies were mainly con- cerned with male labor migration and its effect on the transformation of urban societies, recent research has begun to direct attention to the vital roles of the female and family, and the migrants' ties with home village communities.

Concerning the relation between migration and family composition, the process of migration decision-making has attracted scholarly attention. For example, the book edited by Harbison (1981) was one of the most important works on this issue. Another notable study, by Root and de Jong (1991), using diverse variables, tried to explain family migration, which is considerably different from individual rural-urban migration. The structure of rural families or village communities was also regarded as an important factor, even as to female migration. Such recognition was acknowledged, for example, by Thadani and Torado (1984), who presented a theoretical framework to examine female rural-urban migration, and by Smith et al. (1984), who provided an outline of the general tendencies of female migration among Asian countries.

Thus, it is undeniable that the great influence of women and family on migration trends is becoming recognized. Even in this current of 
thought, however, rural-urban migration of married women has attracted less attention because their mobility has been regarded as simply concomitant to male labor migration (Smith et al. 1984: 22). Even though some researchers such as Williams (1989) examined the postnuptial migration of married couples, his main concern was directed to the rise in social status of women within a household, and thus less attention was paid to its effect on home village communities. Out-migration of married women from rural areas is not only closely related to the substantial change in male circulatory migration, but may also have a great impact on the changes in rural societies, in which married women have an important role in the management of the subsistence economy or the succession of generations. The reason why this point was disregarded in previous research may be attributed to the following condition; even though internal migration study has diversified its perspectives, rural-urban migration still tends to be discussed mainly from the standpoint of the urban landscape, instead of focusing on its influence on the changes of social structure and subsistence activities in rural areas (Hugo 1992: 111). It is easy to anticipate that the multiethnic society, in particular, has diverse factors of out-migration and its complicated results of social transformation in rural areas, which can hardly be comprehended from the rural viewpoint. In this sense, micro-level empirical studies from the rural standpoint are required (Prothero and Chapman 1985: 438439).

Thus, the purpose of this paper is to examine how the substantial change in male circulatory labor migration that was accompanied by the drift of females affects social transformation in rural areas. The research was conducted in Sarawak, a Malaysian state on Borneo Island, which is similar to the prototype of the Southeast Asian archipelago (Tsubouchi 1993: 110). This paper focuses particularly on the village community of the Iban, the largest ethnic group in Sarawak.

\section{The Iban of Sarawak}

The Iban, who are considered typical of the shifting cultivators in Southeast Asia, have cap- tured considerable attention from all quarters because of their conspicuous characteristics, such as wide-range mobility in order to secure land suitable for swidden agriculture, combat strength symbolized by their custom of 'headhunting,' and complicated relations with English rulers. Some of the important literatures on the Iban are, for example, those by Wright et al. (1972) who provided a vivid description of the Iban's life with photographs, Freeman (1955, 1970,1981 ), who conducted social anthropological research on their traditional techniques of swidden agriculture and its relation to the social structure of rural communities, Pringle (1970), who historically examined the Iban's large-scale migration and their rebellions against English sovereigns, which remains instructive to the study of the interrelation between ethnic minorities and the state, and $\mathrm{Pa}$ doch (1982), who investigated the history of the Iban's migration from both an ecological and social perspective. These are indeed precious academic studies that enable us to imagine the Iban's traditional way of life, but contemporary serious issues, such as widespread rapid development and modernization, were not thoroughly clarified because of the time of the writings.

Some articles have dealt with the impact of development and modernization on the Iban society (e.g. Cramb and Wills 1990; Ahmad and Noran 1991), but in-depth investigations on the issues of diverse off-farm employment opportunities, out-migration to urban areas, and their effects on the Iban society, have been provided by only a few scholars, such as Sutlive (1972, 1991) and Kedit $(1980,1993)$. As is pointed out in Sutlive (1992: 128), the Iban began to adopt small-scale rubber planting at the beginning of the twentieth century to supplement their diet of 'traditional' swidden agriculture. The continuous decline of the market price of rubber and the rapid growth of the timber and oil industries in the 1960s propelled the rural-tourban labor migration of Iban males (Cleary and Eaton 1995: 156-157). However, the works of Sutlive and Kedit, based on their foresighted research activities in the late 1960s and the early 1970 s, already seem outdated in the contemporary context, because wider opportuni- 
ties are now open to the Iban. Concerning the recent increase of off-farm employment and its relation to the economic situation and population composition in rural communities, Morrison's (1993) report is informative, but it is unfortunate that sufficient definitive data on the change in social structure at the community level is not provided.

In this paper, we will examine the contemporary socio-economic state of Iban society based on data obtained through empirical field research. The following sections will be devoted to the discussion of two main issues; the rise in socio-economic status of the Iban as it relates to the diversification and stabilization of their job situation in urban areas, and the decline and structural change of rural communities. In order to explain these issues, important factors such as the changing concept of occupation and the increase in female out-migration, and their changing roles in the subsistence economy will be presented.

The research was conducted in an Iban com- munity (Rantau Kemiding Village) in the Kanowit district, where the Iban is the predominant ethnic group. The data shown in this paper is largely dependent on participant observation, interviews with community leaders, and questionnaires distributed to all families in the community, which were obtained during the research periods, of August to September 1995 and June to September 1996.

\section{The Long-house Community in Rantau Kemiding}

\section{Setting}

The study village, Rantau Kemiding, was formed near the junction of the Kanowit River and the Rajang River in the 1920s. The founders of the village had come down from the upper reaches of the Kanowit River under the guidance of the then English ruler, Brooke. Though the Iban are said to have a migratory characteristic, some of them chose to settle

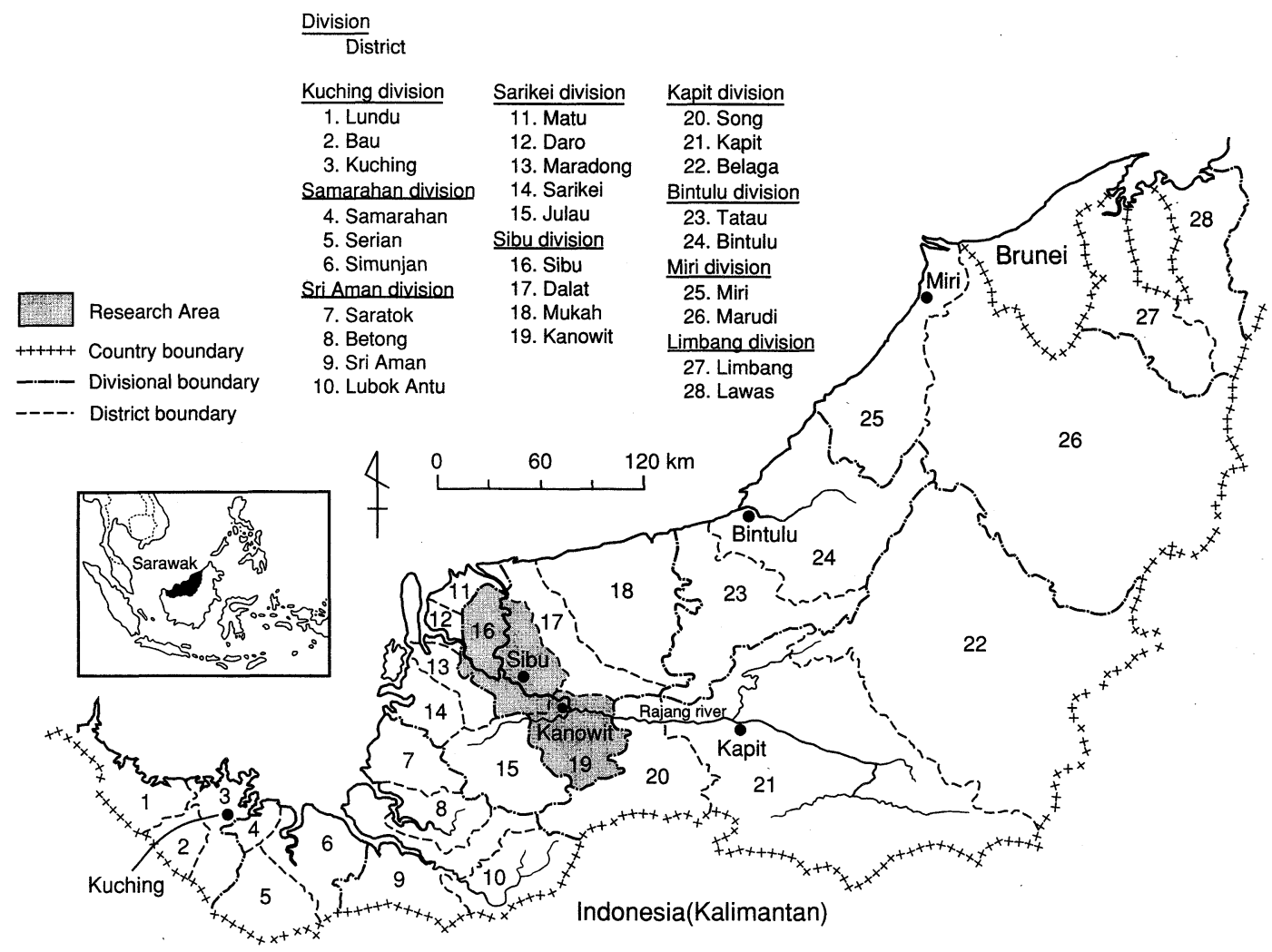

Figure 1. Map showing administrative districts in Sarawak. 
there in order to escape the violent disturbances of the war between the English ruler and Iban warriors on the offensive in the upper stream. The reasons this village was selected for the study area are as follows; through the interaction with the outer world after settling down at Rantau Kemiding, widespread changes occurred in Iban society in the middle reaches of the Rajang, and the process of these changes are thought to be conspicuous. ${ }^{1}$ The Kanowit district (Figure 1), where Rantau Kemiding is located, has a high Iban population $(79 \%$ of a total of 23,633 persons), which is representative of the neighboring districts in the Rajang basin such as the Julau district, Song district, and Kapit district (Yearbook of Statistics Sarawak 1993). What is more, the Kanowit district provides a good research environment for observing the remarkable effects of urbanization on Iban society because the district sends the largest labor population to Sibu, the second largest urban center in Sarawak (Sarawak 1997).

The research village, Rantau Kemiding, is four kilometers south of the town of Kanowit, the administrative center of the Kanowit district. Kanowit is a small market town with a population of 849 (Yearbook of Statistics Sarawak 1993). ${ }^{2}$ People from neighboring villages

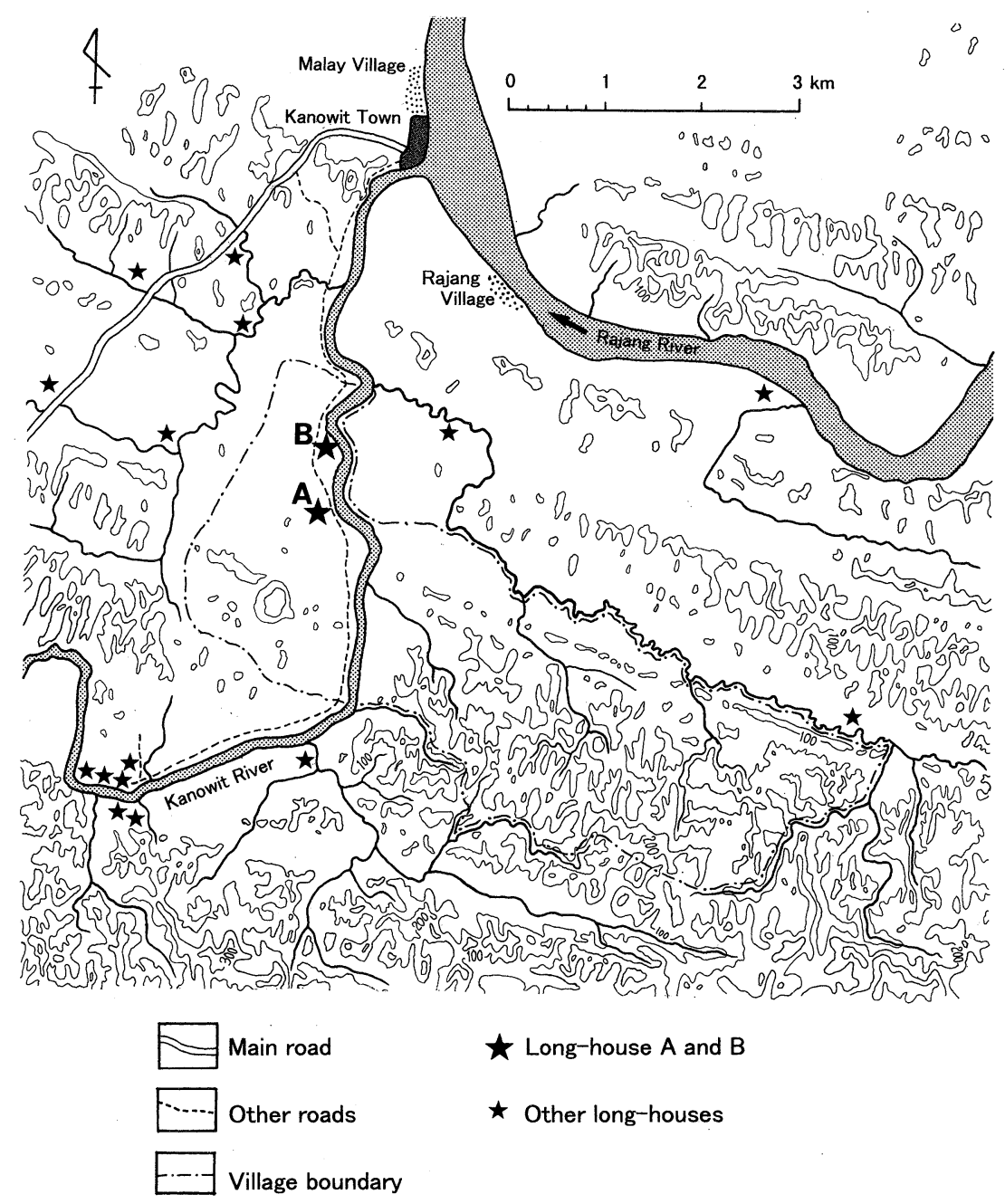

Figure 2. Study area and its surroundings.

Topographical map in 1: 50,000 scale of Kanowit, published by the Overseas Development Administration, United Kingdom 1973, is used as a base map. Contour interval is 100 feet. 
visit the town by bicycle, motorcycle, car, boat, or informal bus to purchase daily goods. Commercial activities in the town are mostly controlled by the Chinese, while there are scattered villages of Malay, Kanowit (Rajang), and Iban surrounding the town (Figure 2). Rantau Kemiding, one of the Iban villages in this area, is composed of two long-houses and six individual houses that contain 69 families and a population of 245 (Table 1).

The Iban is typical of ethnic groups who live in long-houses (Photo 1), which are widely seen in Sarawak and formerly existed extensively in Southeast Asia (Waterson 1990). ${ }^{3}$ A long-house contains a village community within which plural families live together. The interior of the long-house is mainly composed of bileks (separate family rooms) and a ruai (common corridor). ${ }^{4}$ The bilek is the smallest spatial unit in which a stem family is supposed to live. This family unit, usually called a bilek-family, ${ }^{5}$ forms a management unit for swidden agriculture and is rather autonomous both socially and economically. On the other hand, the common corridor, the ruai, runs in front of the bileks from one end of the long-house to the other. This corridor is a highly public space used for meetings, rites, or group work. It also provides people with an opportunity to exchange information in their daily life (Sekine 1979: 68-70). In short, the bilek is a closed and domestic space for the family, and the ruai is a public space for all members of the long-house community that is also open to the outside world. The social life of the Iban is mainly spent in these two sections of a long-house.

\section{Formation of Rantau Kemiding Village as a permanent residence}

This section outlines the organizing process of the long-house community in Rantau Kemiding Village (Figure 3). In 1936, the Iban of Rantau Kemiding built a sturdy 'permanent' long-house (Long-house A), which still exists (Figure 2). The number of bileks when established was 21 (Figure 3). The long-house community at that time was not based solely on lineal relations. The then community leader,

Table 1. Current population of Rantau Kemiding in 1996

\begin{tabular}{lccc}
\hline & $\begin{array}{c}\text { Number of } \\
\text { bilek-families }\end{array}$ & $\begin{array}{c}\text { Number of } \\
\text { empty bileks }\end{array}$ & $\begin{array}{c}\text { Current } \\
\text { residents }\end{array}$ \\
\hline Long-house A & 52 & 7 & 182 \\
Long-house B & 11 & 2 & 48 \\
Individual houses & 6 & 1 & 15 \\
\hline \multicolumn{1}{c}{ Total } & 69 & 10 & 245 \\
\hline
\end{tabular}

Source: Author's field survey.

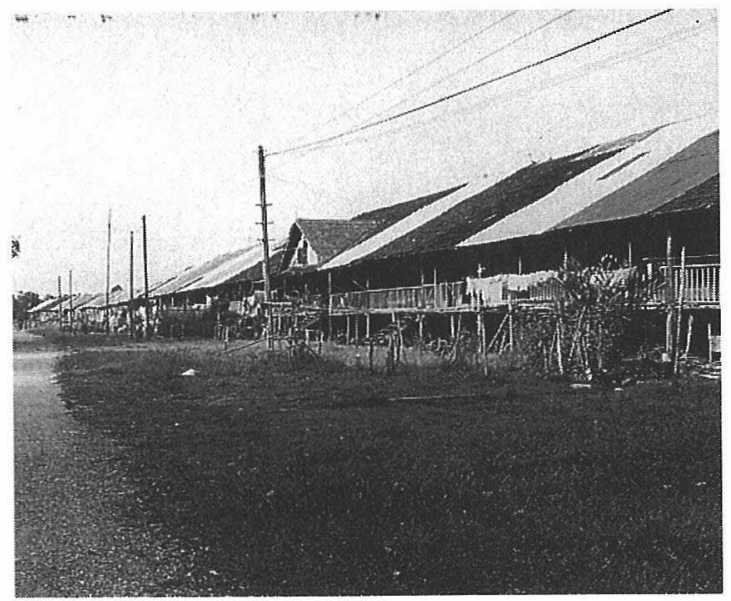

Photo 1. The exterior of long-house A. 
Long-house A

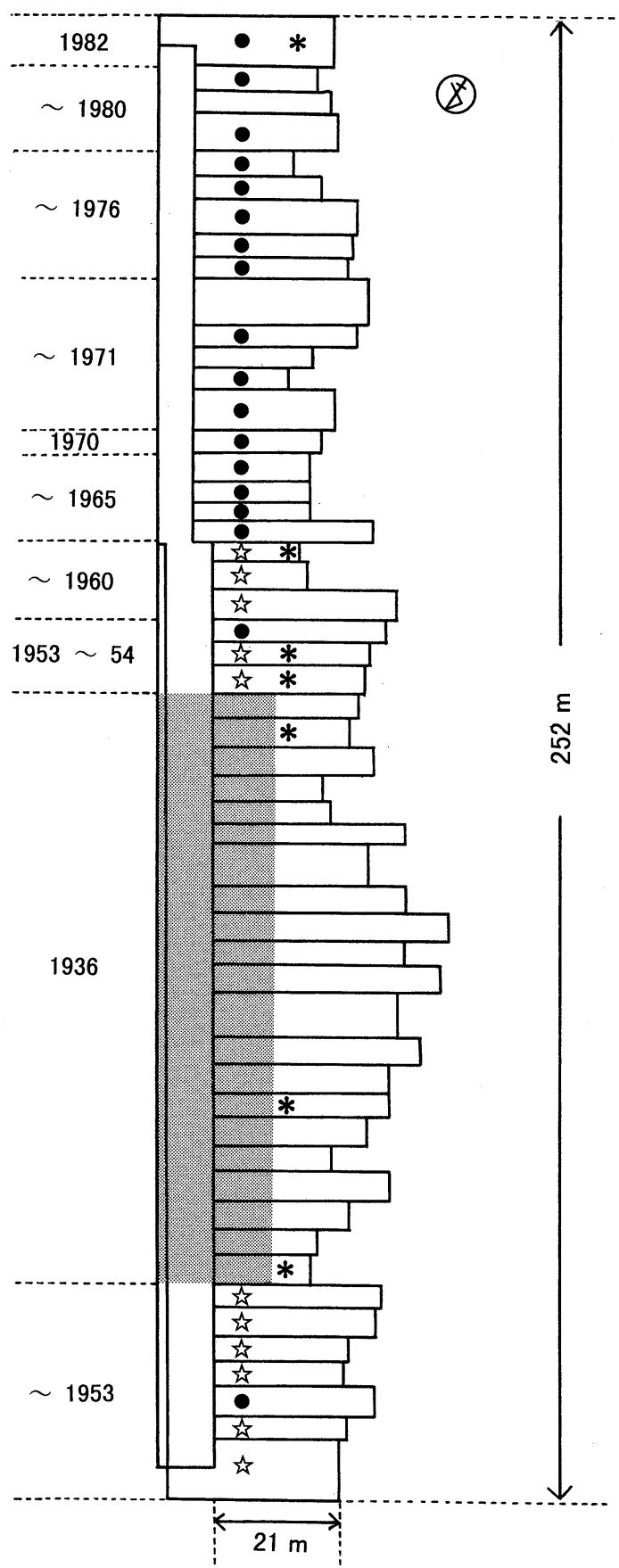

Long-house $B$

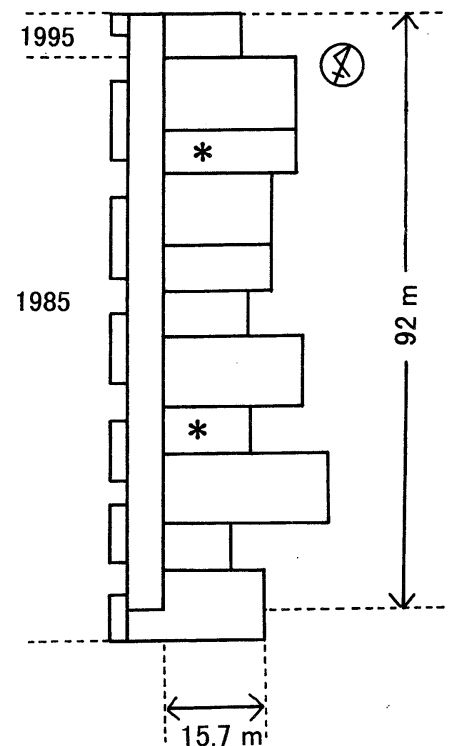

$15.7 \mathrm{~m}$ .

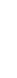

- Bilek established by newly married couple

it Bilek joined with bonds of Christianity

* Empty bilek as of August, 1996

Figure 3. Plan view of the two long-houses in Rantau Kemiding. Numbers on the left indicate the years of the establishment of bileks. Source: Author's field survey. 
who also engaged in mission work at the Kanowit Catholic Church, ${ }^{6}$ accepted some bilekfamilies from other areas through the bonds of Christianity. The inflow of bilek-families from the outside based on religious connections occurred until 1960 (refer to the bileks marked is in Figure 3$)^{7}$

Even after 1960, the long-house continued to extend itself by attaching new bileks on its side. These new bileks were mainly constructed by newly-married couples who had become independent of their parents (bileks marked in Figure 3), including the case of marriage among the same long-house members. Considering that marriage between the same long-house members may strengthen the ties of the bilekfamilies (Freeman 1970: 94), it can be said that the slightly unstable community that had been gathered based on the bonds of lineage and religion has become more solid and steady since the 1960s. In short, Rantau Kemiding experienced both the growth (extension) of the longhouse and the maturity of the community itself in the $1960 \mathrm{~s}^{8}$

However, a group broke away from the community and established a new long-house (Long-house B) in 1985. According to villagers, this breakup was caused by a political event in 1983, when the then Iban-based political party split into two parties, and the subsequent election for the Sarawak State Assembly led to political disagreement between community members. ${ }^{9}$ In this paper, however, we regard these two long-houses as constituents of the same community, because the construction site of long-house B is within the village boundaries (Figure 2), and did not affect the transformation of land occupancy in the village. Furthermore, very close relations between the long-houses remain through the bonds of consanguinity and affinity.

The plan view of long-house $A$ and $B$ is shown in Figure 3. Each bilek has been lengthened backward according to its own financial condition, which does not necessarily reflect on increase in bilek-family members. The extension of a bilek, though not for the satisfaction of their vanity, indicates a rise in economic condition to some extent.

In the process of settling down after the es- tablishment of the 'permanent' long-house in Rantau Kemiding, the Iban also experienced changes in agriculture, especially in paddy and rubber planting. Immediately after the move to this area, they began swidden agriculture on the hilly areas on the other side of the Kanowit River, staying in temporary huts. At the same time, they also began planting rubber trees, which were introduced by the Catholic church. At that time, the Catholic church was trying to modernize agriculture of Iban society with the clear intention of encouraging them to settle down in accordance with Brooke's policy (Rooney 1981: 31-33). Above all, the adoption of rubber planting among the Iban, affected by the rubber boom of the 1910s, prevented them from frequent migration (Sutlive 1992: 128-129). ${ }^{10}$

According to interviews with the villagers, the long-house community of Rantau Kemiding, after settling down there, did not disperse its population to other new fields, but continued to expand their own community. ${ }^{11}$ However, the population increase and accompanying expansion of rubber plantation began to encroach on land that was designated to remain fallow for dry paddy planting in the 1960s. This resulted in the diffusion of wetlands cultivation in combination with the government's wet paddy promotion policy of the $1950 \mathrm{~s}^{12} \mathrm{Be}-$ cause of this government support, intensive cultivation and an increase in rice productivity were achieved to some extent.

Since the 1950s, the spread of agricultural chemicals and fertilizers supplied by the Agriculture Department facilitated farming on wetlands closed to the long-house. ${ }^{13}$ At the same time, rubber diminished in economic value because of the decline of its market price since the 1960s. These factors led to the gradual decline in agricultural activities on remote hill lands. Thus, the Iban began to devote less time to remote farming and spent more time in the long-house. Furthermore, in 1982, the Drainage and Irrigation Department opened a powerdriven irrigation system (127 hectors) at the swampy area northwest of the long-house. As the irrigation area became important for wet paddy cultivation, few people carried out farming at the remote huts. This meant that the long-house of Rantau Kemiding became a 
wholly permanent residence receiving subsistence mainly from wet paddy cultivation.

\section{View of Occupation and Employment Situations}

While the long-house of Rantau Kemiding became a permanent dwelling for the Iban, a new trend of human mobility from the longhouse to urban areas occurred. Acceleration of this migration brought about substantial changes in the community. The main purpose of male migration is to seek jobs in urban areas. In this section, I will describe the changing view of occupation among the Iban males and examine the actual conditions of migration and employment.

\section{Changing view of occupation}

Concerning the words related to job, occupation, or employment, the Iban in the Kanowit area have such variations as pengawa, bejalai, bekuli, and kerja. ${ }^{14}$ Their recognition concerning the relation between these words and their conceptual changes is indicated in Figure 4.

Pengawa has a considerably wide meaning and is used for work in general. Even though pengawa often results in a cash income, the word is also used for daily chores and subsistence activities.

In old days, bejalai meant male "headhunting" expeditions or journeys to search new frontiers. An Iban male was recognized as an adult after completion of such journeys. Even after the Brooke government officially prohibited headhunting, Iban males were still expected to leave the long-house to obtain money or material goods, and ritual preparations for this journey were conducted until recently with some changes in procedures. In this sense, bejalai was a very important cultural system among the Iban (Kedit 1993). The custom of going on journeys was also closely related to the division of labor between the sexes in their daily life. ${ }^{15}$ At present, however, the word bejalai tends to mean only working away from home for cash income.

Bekuli is a derivative of "coolie." This word is widely used to mean unskilled physical labor such as loading work, factory work, and shop assistance. When Iban males go on bejalai, they usually find jobs as bekuli at best. This is especially true for a small market town like Kanowit, where job opportunities are mostly bekuli, except in the government sector.

Kerja is thought to be a relatively new word among the Iban that does not have a cultural connotation. ${ }^{16}$ This word basically means salaried regular employment such as a government servant and company clerk. But the Iban in Kanowit nowadays frequently use this word to mean not only "occupation" but also "work" or "labor" in general. In other words, the concept of "kerja" at present includes short-term waged
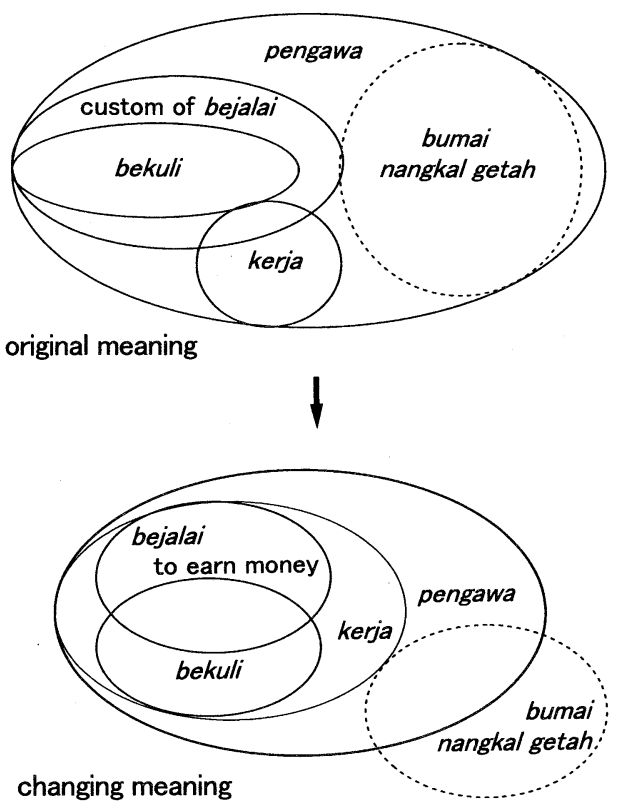

Figure 4. Changing concept of the Iban words concerning occupation.

pengawa: work, business in a broader sense.

bejalai: to go on journeys with a view to acquire wealth, material goods, and social prestige; at the present time the main purpose is to get a job.

bekuli: to do unskilled and hard jobs or short-term wage-labor or coolie.

kerja: to work as salaried employee or non-manual wage-earner; at the present time, it includes wage-labor.

bumai: rice farming

nangkal getah: rubber tapping.

- : work with cash income

............ work in village without wages

Sources: Kedit (1993) and author's field survey. 
labor in the way of bejalai and miscellaneous work (bekuli) by the day.

The changing concepts of these terms seem to reflect the fact that bejalai is losing its social and cultural significance while the definition of kerja is expanding according to the diversification of waged labor. It is noted that the word kerja is seldom used for subsistence agricultural work. Although the word is sometimes applied to commercial plantation labor, other agricultural work has specific words such as bumai for planting paddy and nangkal getah for tapping rubber trees. In particular, those who receive a certain amount of cash income from sources other than agriculture emphasize that their agricultural activity is just a "pastime" (main aja). That is why full-time farmers, if they are questioned on their occupation, usually answer with diffidence that they have no occupation. It seems that at present Iban males attach more importance to gaining cash income by kerja than subsistence agriculture. The following

Table 2. Occupation of the villagers and the out-migrants from Rantau Kemiding

\begin{tabular}{|c|c|c|c|c|c|}
\hline \multirow{2}{*}{ Type of job } & \multicolumn{2}{|c|}{ Stay-in } & \multicolumn{2}{|c|}{ Stay-out } & \multirow{2}{*}{ Total } \\
\hline & $\mathrm{M}$ & $\mathrm{F}$ & M & $\mathrm{F}$ & \\
\hline Government servant & 3 & 1 & 13 & 3 & 20 \\
\hline Teacher & 3 & 2 & 5 & 2 & 12 \\
\hline Clerk & & & 3 & 3 & 6 \\
\hline Political secretary & & & 1 & & 1 \\
\hline Soldier & 1 & & 5 & 3 & 9 \\
\hline Policeman & 1 & & 7 & & 8 \\
\hline Telekom employee & 1 & & 2 & & 3 \\
\hline Company employee & & & 11 & 1 & 12 \\
\hline Company manager & & & 2 & & 2 \\
\hline Shopkeeper & 2 & 2 & 2 & 5 & 11 \\
\hline Cook & & & 2 & & 2 \\
\hline Waiter, Waitress & & & 2 & 1 & 3 \\
\hline Nurse & & & 2 & 1 & 3 \\
\hline Baby-sitter & & 1 & & & 1 \\
\hline Charwoman & & & & 3 & 3 \\
\hline Security guard & 2 & & 3 & & 5 \\
\hline Welder & & & 1 & & 1 \\
\hline Driver & 4 & & 5 & & 9 \\
\hline Tugboat crew & 2 & & 5 & & 7 \\
\hline Construction laborer & & & 8 & & 8 \\
\hline Timber company laborer & & & 9 & 2 & 11 \\
\hline Factory laborer & & & 3 & & 3 \\
\hline Other laborer & 12 & & 9 & & 21 \\
\hline Farmer & 32 & 44 & 3 & 12 & 91 \\
\hline Housewive & & 24 & & 60 & 84 \\
\hline Long-house headman & 2 & & & & 2 \\
\hline Priest & & & 1 & & 1 \\
\hline Persons without regular job & 13 & 10 & 1 & 1 & 25 \\
\hline Pensioner & $\langle 12\rangle$ & $\langle 5\rangle$ & & $\langle 3\rangle$ & $\langle 20\rangle$ \\
\hline Unknown & & & 1 & & 1 \\
\hline Total & 78 & 84 & 106 & 97 & 365 \\
\hline
\end{tabular}

The number of pensioners is counted in the upper types of job.

Refer to note 17 regarding the definition of out-migrants.

Population: household heads and their spouses and children over fifteen years old, except for school attendants, as of August 1996.

Source: Author's field survey. 
subsection discusses the actual working situations of the Iban in the study area.

\section{Working situations of the Iban in the study area}

Table 2 shows the variety of occupations of the villagers and the out-migrants from Rantau Kemiding Village. Table 3 indicates the place of current residence of the out-migrants from the village. The data shown in these tables were collected through the author's interviews with village members. ${ }^{17}$ The findings based on these tables are as follows.

First, the number of farmers (who plant paddy in the village every year) is only 76 of the 162 total stay-in villagers (male: 32 of 78 , female: 44 of 84 ), that is, 47 percent. On the other hand, the stay-in villagers who are employed in the town of Kanowit amount to 31 of total males (40\%). While only six females are employed (7\%), 24 people (29\%) are neither engaged in farming nor waged work (categorized as "housewife"18 in Table 2).
Secondly, there are still a large number of laborers, such as construction workers and timber company employees, among the outmigrants from the village (stay-outs). Contrary to the stereotype that the Iban are unskilled labors, ${ }^{19}$ however, government servants, schoolteachers, company clerks, and company managers are also found, which illustrates the diversification and stabilization of the working situation of the Iban. Even for unskilled work, the contract periods are getting longer. Consequently, those who are engaged in such contract work in urban areas are gradually shortening their stay in the original living base, the long-house.

Thirdly, Table 3 shows that 215 Iban of Rantau Kemiding origin currently live out of the village (stay-out), which is close to the total stay-in population of 245 . Most of the outmigrants from Rantau Kemiding are urban dwellers, except for 18 people (7\%) who live in other long-house communities. ${ }^{20}$ Moreover, most of the out-migrants who live within the

Table 3. Population by the place of current residence and five-year age-group of out-migrants from Rantau Kemiding

\begin{tabular}{|c|c|c|c|c|c|c|c|c|c|c|c|c|c|c|}
\hline \multirow{3}{*}{ Age } & & & \multicolumn{10}{|c|}{ Stay-out } & & \\
\hline & \multicolumn{2}{|c|}{$\begin{array}{l}\text { Total of } \\
\text { stay-ins }\end{array}$} & \multicolumn{2}{|c|}{$\begin{array}{c}\text { Kanowit } \\
\text { district }\end{array}$} & \multicolumn{2}{|c|}{ Sibu district } & \multicolumn{2}{|c|}{$\begin{array}{c}\text { Other } \\
\text { districts in } \\
\text { Sarawak }\end{array}$} & \multicolumn{2}{|c|}{$\begin{array}{c}\text { Other } \\
\text { states in } \\
\text { Malaysia }\end{array}$} & \multicolumn{2}{|c|}{$\begin{array}{c}\text { Other } \\
\text { countries }\end{array}$} & \multicolumn{2}{|c|}{$\begin{array}{l}\text { Total of } \\
\text { stay-outs }\end{array}$} \\
\hline & M & $\mathrm{F}$ & M & $\mathrm{F}$ & M & $\mathrm{F}$ & $\mathrm{M}$ & $\mathrm{F}$ & $\mathrm{M}$ & $\mathrm{F}$ & M & $\mathrm{F}$ & $\mathrm{M}$ & $\mathrm{F}$ \\
\hline $0-4$ & 13 & 11 & & & & & & & & & & & & \\
\hline $5-9$ & 13 & 11 & & & & & & & & & & & & \\
\hline $10-14$ & 15 & 9 & 1 & & & & & & & & & & 1 & \\
\hline $15-19$ & 6 & 12 & 1 & 3 & 4 & 3 & & 3 & 2 & & & & 7 & 9 \\
\hline $20-24$ & 8 & 11 & 1 & & 5 & 3 & 8 & 7 & & & & & 14 & 10 \\
\hline 25-29 & 7 & 3 & 2 & 6 & 13 & 5 & 7 & 10 & 1 & 1 & 1 & & 24 & 22 \\
\hline $30-34$ & 6 & 8 & 5 & 5 & 7 & 11 & 4 & 4 & 2 & & 2 & & 20 & 20 \\
\hline $35-39$ & 3 & 8 & 3 & 4 & 6 & 8 & 5 & 4 & 4 & 3 & & & 18 & 19 \\
\hline $40-44$ & 7 & 5 & 4 & & 5 & 6 & 1 & & & & 1 & 1 & 11 & 7 \\
\hline $45-49$ & 5 & 7 & 2 & 1 & 2 & 2 & 4 & & & & & & 8 & 3 \\
\hline $50-54$ & 6 & 7 & 1 & 1 & & & & 1 & & & & & 1 & 2 \\
\hline $55-59$ & 9 & 10 & & & & & 1 & & & & & & 1 & \\
\hline $60-64$ & 7 & 6 & & & & & & & & & & & & \\
\hline $65-69$ & 5 & 6 & & & & & & & & & & & & \\
\hline $70-$ & 8 & 9 & & 1 & & & & & & & & & & 1 \\
\hline Unknown & 2 & 2 & & 3 & 3 & 6 & 1 & 2 & 1 & & 1 & & 6 & 11 \\
\hline Total & 120 & 125 & 20 & 24 & 45 & 44 & 31 & 31 & 10 & 4 & 5 & 1 & 111 & 104 \\
\hline
\end{tabular}

Population: household heads and their spouses and children as of August 1996

Source: Author's field survey. 
Kanowit district are employed in the town of Kanowit. Even taking into consideration the means and expense of transportation, they can commute between the village and the town by bicycle, motorcycle, car, or illegal bus, but they prefer living in the town.

Among the job variations in Table 2, only a few types of jobs are immediately recognized as bejalai at present. If one is employed within commuting range, people never recognize that person as on bejalai. This is the same as the case of one who secures full-time employment in other urban areas. Even among those who are engaged in physical labor pursuant to a short-term contract in a remote area, some do not recognize themselves as being on the bejalai tour.

At present, a realistic value judgment for the Iban's working experience is based on whether they have a kerja as regular work rather than on whether they have performed the journey of bejalai. The expanding meaning of the word kerja, which is drawn in Figure 4, is the result of the shift in emphasis from bejalai to kerja and the diversification of the Iban's employment situation. Bejalai is a kind of circular labor migration mainly for obtaining consumer goods or cash for remittance with a clear view to returning home. However, corresponding to the changing concept of the Iban words for occupation, the period of a young Iban's sojourn in urban areas is getting considerably longer, which may make defining it as circulatory migration inappropriate. This new tendency in labor migration is closely correlated with the changes in population composition and subsistence activities in the village. This matter will be discussed in the following section.

\section{Female Migration and Subsistence Activities}

\section{Out-migration accompanied by a wife and children}

An important phenomenon emerging in accordance with the changes in the job situations of Iban males is the trend of female outmigration. At one time a tolerant division of labor between the sexes was accepted among the Iban society in which males were expected to work outside the village to make a fortune or reputation, and females were supposed to take care of their family and the paddy fields for self-sustenance (Freeman 1970: 75; Sutlive and Appell 1991: xix; Morrison 1993: 53). As the Iban society is based on a bilineal kin system, heirship of a bilek is open to any child who intends to stay with the parents after marriage, regardless of sex or seniority (Uchibori 1996: 58). The absence of a strict rule of succession is reflected in the relaxed social restrictions on the drift of the young generation from the longhouse. Therefore, in Iban society, where longterm journeys of adult males are taken for granted, parents can ease their anxiety for the future if they have a married daughter or a daughter-in-law staying with them in the same bilek.

As Table 3 shows, however, for those originating in the Rantau Kemiding village, the number of females who currently live outside the village is 104 out of a total of 229 , which is not very different from the rate of male stayouts (111 out of 231). The rate of female stayouts is relatively higher compared to the past. Villagers explained that the increase in female out-migration was a rather recent trend, which had been accelerated by the relatively stabilized income and improved living conditions of their husbands who were working in urban areas. It should be noted that, as Table 4 shows, a certain number of the urban dwellers secured relatively more stable residences such as government quarters (38\%; 74 out of 197) and individual houses (15\%; 29 persons). Moreover, according to Table 2, while males are engaged in various occupations, a large number of females $(62 \%$; 60 out of 97$)$ are not employed, and stay at home as "housewife."21

The diversification and stabilization of the Iban males' employment and the accompanying phenomenon of female rural-to-urban migration are thought to result from the change in the industrial structure in Sarawak; since the decline of the rubber market price, the Sarawak government has been promoting industrial diversification instead of excessively depending on the export of agricultural products or raw materials, such as timber, oil, and natural gas 
Table 4. Type of residence by marital status and sex in 1996

\begin{tabular}{|c|c|c|c|c|c|}
\hline \multirow{2}{*}{ Type of residence } & \multicolumn{2}{|c|}{ Single } & \multicolumn{2}{|c|}{ Married } & \multirow{2}{*}{ Total } \\
\hline & $\mathrm{M}$ & $\mathrm{F}$ & $\mathrm{M}$ & $\mathrm{F}$ & \\
\hline Long-house $\mathrm{A}$ and $\mathrm{B}$ & 64 & 67 & 50 & 52 & 233 \\
\hline Individual house (within the village) & 2 & 2 & 4 & 4 & 12 \\
\hline Individual house (outside the village)* & 3 & 3 & 9 & 14 & 29 \\
\hline Government Quarters* & 7 & 4 & 28 & 35 & 74 \\
\hline Rented houses or room* & 10 & 3 & 16 & 10 & 39 \\
\hline Company dormitory* & 10 & 2 & 10 & 10 & 32 \\
\hline Other long-house & - & - & 6 & 12 & 18 \\
\hline School dormitory* & 3 & 7 & - & - & 10 \\
\hline Others, Unknown & 4 & 0 & 5 & 4 & 13 \\
\hline Total & 103 & 88 & 128 & 141 & 460 \\
\hline
\end{tabular}

(Danaraj 1995: 28). ${ }^{22}$ Indeed, it is difficult to deny that the majority of Iban males in urban areas are still largely dependent on unstable job opportunities, but it is also true that their lives have been gradually improving to make it possible for the family to migrate with the husband to urban areas.

Some writings based on the research conducted in the 1970 s and the early 1980 s described the rapid increase of male labor migration induced by the growth of the timber and oil industries and its social impact on the life of females who remained in the village (Kedit 1993), or emphasized the rural-to-urban migration of divorced females for the purpose of prostitution activities (Sutlive 1991). But such male-female relations among the Iban society are nowadays rarely observed in the Kanowit district. According to the interviews with Iban women who live with their husbands in urban areas, the purpose of their migration was partly to release themselves from the tedious life or human relationships in the village and, more positively, to provide their children with a better education. ${ }^{23}$ For the aged people in the village, remittances from their children are still an important source of income, but the migration of younger people attaches more importance to investment in the next generation. In Rantau Kemiding Village there were three wives living apart from their husbands in town as of August 1996. Two of them were sojourning with their parents only temporarily in order to take care of their infants with their parents' assistance. Therefore, they did not participate in agricultural work and also articulated their intention to go back to their husband after a few months or so.

If a male migrates from a rural to urban area with his wife and children, he is not considered to be on the journey of bejalai. Nowadays, bejalai of Iban males as a short-term circulatory migration has been decreasing, while family migration and long-term sojourning in urban areas are becoming popular, underpinned by the increased opportunities of steadier, regular work, kerja. There are certainly many urban dwellers who are going to enjoy retired life in their home village after a long-term stay in town, but it is too naive to consider this trend to be a change of the migration cycle. What is a point to notice is the potential for the improvement of the socio-economic status of the next generation who may remain in urban areas. In short, family migration has a different aspect from previous circulatory migration that aims to transfer wealth from urban to rural areas; instead, it is characterized by deliberate longterm sojourn for the purpose of accumulating a fortune through generations in urban areas. This means that the important unit of the bilekfamily composition is changing. While longestablished continuity of generations within a bilek had not necessarily presupposed that a married couple always live together in the bilek, the recent migration trends seem to attach 
more importance to the bonds of a nuclear family based on the married couple. This change may affect the substantial transformation of the long-house community, which will be discussed later herein.

\section{The aging population and the decline in agri- cultural activities}

Recently, because married women are increasingly out-migrating from the long-house to follow their husbands who are employed in urban areas, a major part of the agricultural activities in the village is are being performed by the elderly. Table 5 shows the working population in Rantau Kemiding listed by age and sex, of which 57 percent of full-time farmers are 50 years old and over. This aging farm population is accompanied by substantial changes in agricultural activities.

During the farming season of 1995/1996, 44 out of a total of 59 bileks carried out paddy cultivation including farming as a side job. ${ }^{24}$ The status of paddy planting of each bilek is shown in Table 6. This table illustrates several important points. First, the major form of farming is shifting from dry paddy planting to wet paddy planting in swamps or irrigated fields. The number of bileks that planted paddy on hilly areas and dry flat lands is only 8 and 12 respectively, but the bileks that performed wet paddy planting amounted to 37 . Regarding the planted acreage, the total area under wet paddy cultivation in the village was 65.6 acres while dry paddy occupied 22.8 acres. ${ }^{25}$ Each bilek has
1.7 different types of dry paddy on average and 3.7 types of wet paddy on average. Out of the total 39 types found in the whole village, 15 types had adaptability to dry land while 36 types were adaptable to swamp or irrigated land. ${ }^{26}$

Secondly, there is a tendency of continuous cropping on the same land. It was taken for granted that the paddy planting in the Iban community was dependent on shifting cultivation, whether on dry or swampy land (Pringle 1970: 26), but at the time of the author's research (1996) there were 10 bileks that had been planting wet paddy on the same land for more than three years, and most of the other paddy fields were also utilized with a very short period of fallow.

The third point is the shrinkage of the average planted acreage. According to the report of Freeman (1955), who conducted his research between 1949 and 1951 in the Balleh Basin, a tributary of the Rajang River, the average planted area of paddy was nearly five acres, while that in Rantau Kemiding in 1996 was 2.01 acres (there were only two bilek-families who planted more than five acres). According to the Rantau Kemiding villagers, there were many bilek-families that cultivated more than five acres in the 1960s, but in the 1970s, the planted acreage began to shrink gradually.

It is said that the ratio of planted wet paddy began to exceed that of dry paddy in the late 1960s. The likely reasons for this change were that the Sarawak government had continu-

Table 5. Working population by age and sex in Rantau Kemiding in 1996

\begin{tabular}{|c|c|c|c|c|c|c|c|c|c|}
\hline \multirow{2}{*}{ Age } & \multicolumn{2}{|c|}{$\begin{array}{c}\text { Farmers } \\
\text { (full time) }\end{array}$} & \multicolumn{2}{|c|}{$\begin{array}{l}\text { Non-farm } \\
\text { employees }\end{array}$} & \multicolumn{2}{|c|}{$\begin{array}{c}\text { Unemployed, } \\
\text { Housewife }\end{array}$} & \multicolumn{3}{|c|}{ Total } \\
\hline & M & $\mathrm{F}$ & M & $\mathrm{F}$ & M & $\mathrm{F}$ & $\mathrm{M}$ & $\mathrm{F}$ & Subtotal \\
\hline-19 & 1 & & 2 & 1 & 2 & 2 & 5 & 3 & 8 \\
\hline $20-29$ & 2 & 3 & 7 & 2 & 5 & 8 & 14 & 13 & 27 \\
\hline $30-39$ & 2 & 9 & 6 & 1 & 1 & 6 & 9 & 16 & 25 \\
\hline $40-49$ & 5 & 8 & 6 & 1 & 1 & 3 & 12 & 12 & 24 \\
\hline $50-59$ & 8 & 9 & 6 & 1 & 1 & 7 & 15 & 17 & 32 \\
\hline $60-$ & 13 & 13 & 5 & & 3 & 8 & 21 & 21 & 42 \\
\hline Unknown & 1 & 2 & 1 & & & & 2 & 2 & 4 \\
\hline Total & 32 & 44 & 33 & 6 & 13 & 34 & 78 & 84 & 162 \\
\hline
\end{tabular}

Population: equal to "stay-ins" in Table 2

Source: Author's field survey. 
Table 6. Status of paddy cultivation in Rantau Kemiding in 1996

Long-house A

\begin{tabular}{|c|c|c|c|c|c|c|c|c|c|c|}
\hline \multirow[b]{2}{*}{$\begin{array}{l}\dot{a} \\
\dot{0} \\
\frac{\overrightarrow{0}}{\tilde{D}}\end{array}$} & \multicolumn{3}{|c|}{ Population } & \multicolumn{3}{|c|}{ Area (in acres) } & \multicolumn{2}{|c|}{ Variety } & \multirow{2}{*}{ 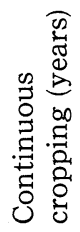 } & \multirow{2}{*}{ 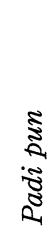 } \\
\hline & $\sum_{\sum}^{\frac{0}{\pi}}$ & 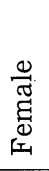 & $\begin{array}{l}\underset{\pi}{0} \\
\stackrel{0}{\oplus}\end{array}$ & 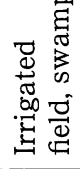 & 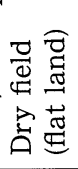 & 浔 & 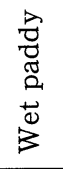 & 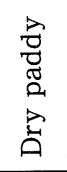 & & \\
\hline & - & - & - & - & 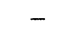 & - & & & & \\
\hline & 1 & 1 & 2 & 1.5 & & & 4 & 0 & 1 & O \\
\hline & 3 & 2 & 5 & 1 & & & 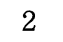 & 0 & & (a) \\
\hline & 2 & 3 & 5 & - & 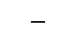 & - & & & & ? \\
\hline & 2 & 1 & 3 & 3 & & & 4 & 0 & & (a) \\
\hline & 2 & 1 & 3 & 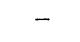 & - & - & & & & $\triangle$ \\
\hline & 1 & 1 & 2 & & 1.5 & mit & 0 & 3 & & $\overrightarrow{0}$ \\
\hline & 3 & 2 & 5 & 1 & & & 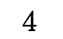 & 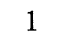 & & (a) \\
\hline & 2 & 2 & 4 & n.a. & n.a. & n.a. & n.a. & n.a. & n.a. & n.a \\
\hline & 2 & 2 & 4 & 1.5 & 0.8 & & 1 & 0 & & (a) \\
\hline & 3 & 3 & 6 & 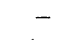 & 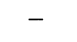 & - & & & & $\triangle$ \\
\hline & 5 & 4 & 9 & 1 & & & 4 & 0 & & $\bar{x}$ \\
\hline & 3 & 3 & 6 & 1 & & mit & $?$ & 2 & & (2) \\
\hline 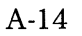 & 3 & 3 & 6 & 2.5 & mit & & 5 & 1 & & $\bigcirc$ \\
\hline & 2 & 4 & 6 & 2 & & & 4 & 0 & & 8 \\
\hline & & 1 & 1 & 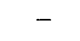 & - & - & & & & $?$ \\
\hline & 1 & & & 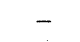 & & 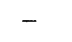 & & & & $\triangle$ \\
\hline & 3 & 5 & 8 & 3 & mit & & 7 & 0 & 1 & 0 \\
\hline & - & - & & - & - & - & & & & 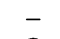 \\
\hline 20 & 2 & 4 & 6 & 2 & mit & & 9 & 2 & & 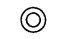 \\
\hline 21 & 4 & 2 & 6 & 2.5 & & 3 & 1 & & & $\bigcirc$ \\
\hline 22 & & 1 & 1 & 1 & & 0.5 & 2 & 2 & & (2) \\
\hline 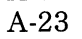 & - & - & 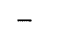 & 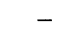 & - & 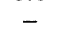 & & & & 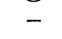 \\
\hline & - & - & 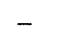 & 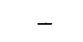 & - & - & & & & 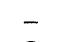 \\
\hline 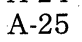 & 1 & 2 & 3 & 2 & & & 9 & 0 & 15 & (a) \\
\hline 5 & - & - & & - & 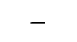 & 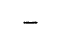 & & & & \\
\hline 7 & 1 & 2 & 3 & 2 & mit & & 3 & 1 & & (a) \\
\hline 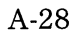 & 1 & 1 & 2 & - & 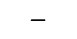 & - & & & & $\triangle$ \\
\hline 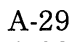 & & 1 & 2 & - & - & - & & & & $\times$ \\
\hline 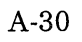 & 1 & 1 & ? & 2 & mit & & 3 & 1 & & (a) \\
\hline 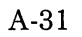 & 4 & 2 & 6 & 1 & 1 & & n.a. & 11 & & x \\
\hline 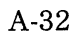 & 2 & 3 & 5 & & & 2 & 0 & & & (a) \\
\hline 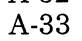 & 3 & 3 & 6 & 2 & & & n.a. & n.a. & 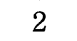 & $?$ \\
\hline & 2 & 2 & 4 & - & - & - & & & & (C) \\
\hline 35 & 2 & 2 & 4 & 0.8 & & & 2 & 0 & 1 & (a) \\
\hline & 2 & 2 & 4 & - & - & - & & & & 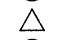 \\
\hline 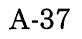 & 2 & 2 & 4 & 0.5 & 0.5 & & 4 & 1 & & (O) \\
\hline 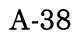 & & 3 & 3 & & 0.5 & & 0 & 2 & 1 & $\triangle$ \\
\hline 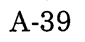 & - & - & 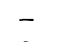 & 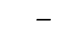 & - & 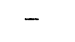 & & & & 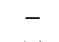 \\
\hline & 2 & 1 & 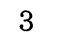 & - & . & & & & & \\
\hline & 2 & 2 & 4 & 1 & & 1 & 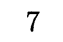 & & & ? \\
\hline & 1 & 2 & 3 & 1 & & 1 & 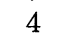 & 1 & & $\wedge$ \\
\hline & & 1 & 1 & - & - & - & & & & \\
\hline 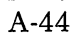 & & 3 & 3 & 5 & & & 3 & 0 & 1 & (a) \\
\hline 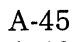 & - & - & 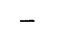 & - & - & - & & & & 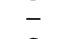 \\
\hline & 6 & 2 & 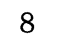 & 1.3 & & & 1 & & & $\Omega$ \\
\hline & 1 & 1 & 2 & 1 & & & & & & \\
\hline & 3 & 2 & 5 & 3 & & & ก & & & \\
\hline & 3 & 2 & 5 & 2 & & & 3 & & & \\
\hline 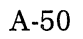 & 1 & & 1 & 2 & & & 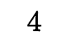 & & 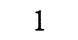 & $:$ \\
\hline & 3 & 2 & 5 & & $Z$ & & 2 & 1 & 1 & (a) \\
\hline-52 & 2 & 4 & 6 & 2 & & mit & 1 & 1 & 1 & ๑ \\
\hline Total & & 93 & & & 6.3 & 1.0 & 3.7 & 1.5 & 2.0 & \\
\hline
\end{tabular}

Long-house B

\begin{tabular}{|c|c|c|c|c|c|c|c|c|c|c|}
\hline \multirow[b]{2}{*}{ 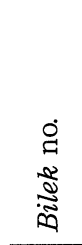 } & \multicolumn{3}{|c|}{ Population } & \multicolumn{3}{|c|}{ Area (in acres) } & \multicolumn{2}{|c|}{ Variety } & \multirow{2}{*}{ 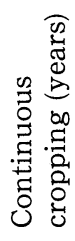 } & \multirow{2}{*}{ 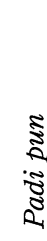 } \\
\hline & $\frac{\stackrel{0}{\pi}}{\sum}$ & 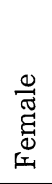 & 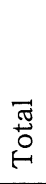 & 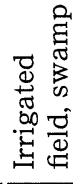 & 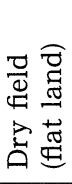 & 浔 & 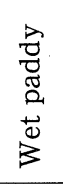 & 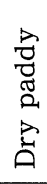 & & \\
\hline B-1 & 1 & 1 & 2 & 3.5 & 0.5 & & 5 & 1 & 5 & (a) \\
\hline B-2 & 2 & 3 & 5 & - & - & - & & & & $\triangle$ \\
\hline B-3 & 3 & 3 & 6 & 2 & & 1.5 & 4 & 1 & 1 & (a) \\
\hline B-4 & - & - & - & - & - & - & & & & - \\
\hline B-5 & 2 & 2 & 4 & 0.5 & 0.5 & & 1 & 1 & 1 & 0 \\
\hline B-6 & 2 & 4 & 6 & 1 & & & 2 & 0 & 1 & 0 \\
\hline B-7 & 1 & 1 & 2 & & 1 & 1 & 0 & 4 & 1 & $?$ \\
\hline B-8 & 4 & 3 & 7 & - & - & - & & & & $x$ \\
\hline B-9 & - & - & - & - & - & - & & & & - \\
\hline B-10 & 7 & 6 & 13 & 0.5 & 0.5 & & 2 & 3 & 1 & 0 \\
\hline B-11 & 2 & 1 & 3 & & & 3 & 2 & 2 & 1 & (0) \\
\hline Total & 24 & 24 & 48 & 7.5 & 2.5 & 5.5 & 2.7 & 2 & 1.6 & - \\
\hline
\end{tabular}

Individual houses

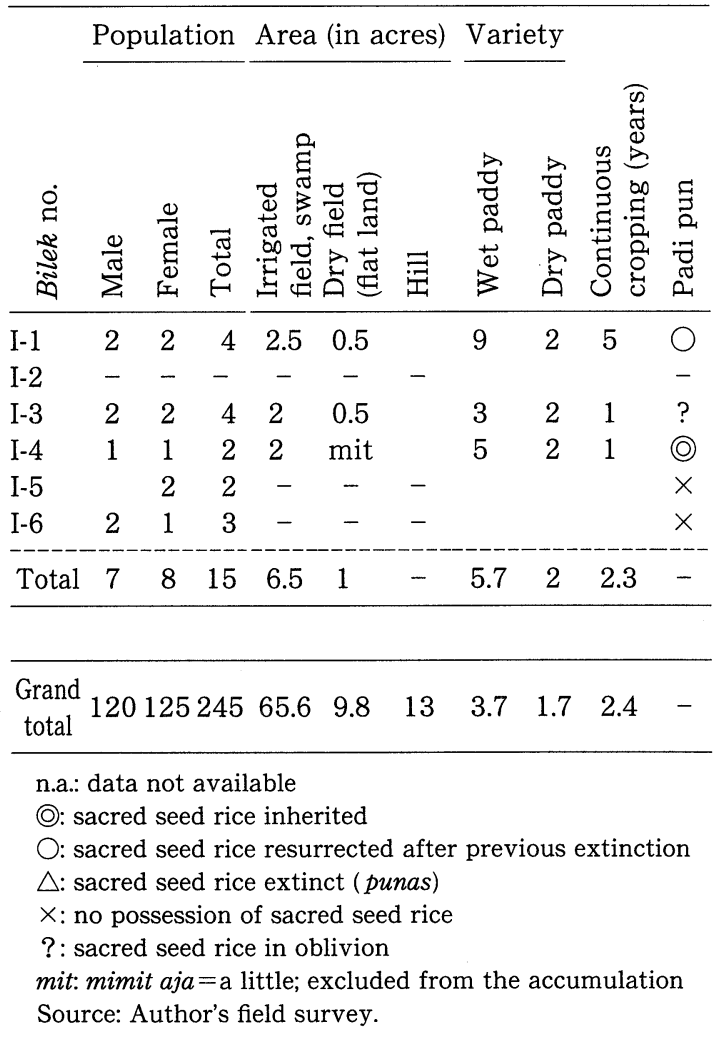


ously promoted wet paddy cultivation since the 1950s and that most of the hilly land had by this time been already covered with rubber trees. In the late 1960s there was very little hilly area without rubber trees planted and it was also difficult to find secondary forest that had been left fallow for a long enough period. Because the soil fertility of shortly-fallowed land is usually unsatisfactorily recovered and subject to damage caused by disease and harmful insects, extra work such as fertilizing and chemical treatment is required in order to obtain a settled harvest. Therefore, even taking into account the tiresome work of weeding, the villagers preferred cultivating wet paddy in marshy areas close to the long-house, and when they planted dry paddy they tended to choose flatland to minimize their efforts. Furthermore, the establishment of pumped irrigation in 1982 facilitated the continuous cropping of wet paddy. The tendency of alleviating agricultural work and reducing paddy cultivation area has been strengthened by the decrease in the agricultural labor force, the rise in the ratio of the aged population, and the increase in the opportunity for side jobs.

\section{Custody of "padi pun" and the extinction of the bilek-family}

The Iban culture is often called a paddy cult. The cultural importance of the Iban's paddy cultivation is emphasized especially in ritual activities and inheritance (Pringle 1970: 30). This subsection will describe the status of inheritance of the sacred rice, "padi pun," which symbolizes the succession of the bilek-family, and examine its relation to the change in subsistence activities.

The Iban recognize the sacred rice, padi pun, as their "root," which is inherited by children from their parents and prohibited from transfer to others. The genealogy based on the bilek is the only measure for the Iban to identify their origins; therefore, the inheritance of the sacred rice is an important symbol of the bilek-family in straight succession (Uchibori 1996: 52). ${ }^{27}$ The seed rice (usually dry rice) inherited from ancestors is supposed to be planted every year. When they cannot plant the sacred rice themselves due to unavoidable circumstances, the
Iban ask close relatives to plant it to prevent its extinction.

In spite of such efforts, the inherited sacred rice may become extinct accidentally; for example, there may be no harvest because of disease or harmful insects, or the seed rice may disappear due to sloppy safekeeping during the agricultural off-season. Extinction of the sacred seed rice is called punas in the Iban language. This word originally meant that a married couple is not blessed with a child or a bilek-family is extirpated. In this sense, too, the sacred rice can be said to have a symbolic meaning in the succession of the bilek-family.

According to Table 6, out of the 44 bilekfamilies who did paddy cultivation in 1996, 31 bilek-families planted sacred rice (marked () and $\bigcirc$ ), eight bilek-families had let the inherited sacred rice die out (marked $\triangle$ ), and five bilekfamilies had not inherited sacred rice from their parents (marked $\times$ ). Furthermore, even among the 31 bilek-families who maintained their sacred rice, 10 bilek-families did not plant authentic rice. In reality, these families had experienced punas of the sacred rice in the past and resumed paddy cultivation by substituting seed rice given by other bilek-families for their own sacred rice (marked $\bigcirc$ ). Thus, the tradition of succeeding to the authentic sacred seed rice was successfully continued by only 21 bilekfamilies (marked (0), which is less than half of the total families that planted paddy.

In principle, women are responsible for the management of the paddy. In Iban paddy cultivation, there is a division of labor between the sexes, though it is not strict. While men play central roles in dangerous and heavy labor, such as opening forests, burning the opened fields, and making holes for seeding, women are expected to take the initiative in sowing, weeding, harvesting, wet paddy nursing, and transplanting. In addition, women are responsible for selecting which species of paddy to plant, safekeeping of the seed rice during the agricultural off-season, and taking measures to avoid punas, which most males are indifferent to. Thus, the status of females regarding the succession of sacred rice is very important.

According to the villagers, the abovementioned tendency of extinction of the sacred 
rice succession is caused by several factors, namely, the shift from dry paddy cultivation to wet paddy cultivation (sacred rice is usually used for dry paddy), the stagnation of subsistence activities because of the decrease in the agricultural labor force (yearly cropping has become difficult), and sloppy safekeeping (the absence of married women as safe keeper of the seed rice or the lack of close communication between bileks). ${ }^{28}$

The bilek not only maintains high autonomy as a managing unit of paddy cultivation but also functions as a place for inheriting sacred rice, land usufruct, agricultural implements, and other household property. In other words, the bilek is important as both a living space and a basis for identifying one's family line, and its continuity is symbolized particularly by the inheritance of sacred rice in which females play an important role. In this sense, the relation between the absence of females and the tendency towards extinction of bilek succession should be noted from the perspective of the decline of the cultural tradition of inheritance.

\section{Structural Degradation of the Long-house Community}

As was discussed above, the diversification and stabilization of the Iban males' working circumstances and their long-term sojourn in urban areas have given rise to female outmigration and, subsequently, the decline of subsistence activities in the village. In order to clarify how these phenomena affect Iban society, it is necessary to examine them from the perspective of the long-house as a living space. There is a dichotomy commonly recognized in Iban society that contrasts male, outside, and dynamic with female, inside, and static. This dichotomy is closely related to the spatial composition in a long-house, that is, the ruai, symbolized as an open and public space for men, and the bilek, symbolized as a closed and private space for women (Sekine 1979: 60-73; Sutlive 1991: 493; Uchibori 1996: 46-48). ${ }^{29}$

The bilek is the basis for the succession of the bilek-family. When an Iban refers to his origin, he usually attaches importance to the continuity of the bilek, not to the history of the long- house (Uchibori 1996: 52-53). The continuity of the bilek is, as it were, based on the culture of rice producing, as is observed in the way land and sacred rice are inherited, but that continuity is now subject to extinction. For example, Table 6 shows that in Rantau Kemiding Village there are six persons (two males and four females) who live alone in a bilek. They are all elderly people. ${ }^{30}$ In addition, five bilek-families are composed only of one married couple whose household heads are above 55 years old. The other 10 bileks are empty. These three types of bilek compositions account for 30.4 percent of the long-house community (21 out of 69 bileks). This not only indicates that the long-house community is beginning to resemble an "old people's home," ${ }^{31}$ but also augurs the difficulty in passing the inheritance of the bilek to the younger generations.

On the other hand, it can be said that the public space of the ruai symbolizes the longhouse community itself in that the community is composed based on territorial relations with the reticulation of affinity and consanguinity. In this sense, social functions fulfilled in the ruai reflect the solidarity of the community (Sekine 1979: 72). However, it is obvious that the important aspect of the ruai as an assembly space has been gradually tapering off. The changes in agricultural activities, such as the decrease in the size of the planted area, the shift from dry to wet paddy cultivation, and the fixation of the paddy fields, have made it unnecessary to mutually confirm planted areas of the year and to arrange large-scale group work or labor exchanges between bilek-families. This is why there has been no long-house meeting concerning agricultural activities in the community since the 1980s. In addition, assemblies for performing agricultural rituals and other daily gatherings have been declining.

It is easily surmised that the loosened bonds in the long-house community correspond to the decline in the above-discussed agricultural activities. However, some villagers also emphasized that the excessive expansion of the community caused the loosening of solidarity, which was reflected in the deterioration of the public characteristics of the ruai. They also pointed out that politics at ruai meetings and 
political events of the outside world affected the split of the community (establishment of Long-house B) in 1985. These tendencies prove Sutlive's (1972: 458-459) prospect of the decline in social importance of the ruai, which is rapidly adversely affecting the solidarity of the community.

The two major sections of a long-house, bilek (separate room to confirm a lineal relation) and ruai (common corridor to reinforce territorial relations), have been interrelated to loosen its own social functions. This is a fundamental problem that not only affects the integration of the community, but also threatens the existence of long-house itself.

In the colonial period, the Iban's migration was restrained under the influence of the British and Chinese. Their choice to settle down in a permanent residence subsequently gave rise to the decline in agricultural activities, especially dry paddy cultivation in distant places, which reduced life in remote farm huts. This change physically stabilized the long-house and reinforced its character as a permanent place of residence. However, in the process of stabilizing the long-house as a permanent residence, the dispersion of the enlarged population to new frontiers became stagnant because of various restrictions, such as the beginning of rubber planting and the relative decrease in uninhabited forests. This resulted in the excessive expansion of the long-house community. ${ }^{32}$ In the 1960s and the 1970s, the sequential addition of bileks to the long-house occurred pursuant to the natural increase of the population, which gave rise to various internal frictions including political conflict. In addition, after the climax of its stabilization, the long-house community began to face various problems such as the out-migration of the younger generations including females, aging of the population, decline of agricultural activities, and weakening of solidarity in the community, all of which were closely related to the diversification of male employment opportunities in urban areas. This phenomenon can be called the "structural degradation" of the long-house community.

In short, from the perspectives of both subsistence activities and social bonds, the affir- mative reason for the existence of the longhouse community is tapering off; instead, with the outflow of the leading younger generations in the community, the long-house is becoming a place for youths who cannot find jobs and who passively engage in agriculture and, for the aged who have given up sojourning in urban areas.

\section{Concluding Remarks}

The focus of many studies about outmigration from rural areas and its impact on rural communities in Southeast Asia has been institutionalized circulatory labor migration as a supplement to the rural economy, namely, the unremitting flow of wealth from urban to rural areas and the penetration of the monetary economy into rural areas. Even though attention is beginning to be paid to female migration, scholars' main interest has been in the circulatory migration of single women and its effects on the economic structure. There have not been satisfactory descriptions of the effect of female migration on social structures in rural communities. This paper, using the Iban society in Sarawak, points out the change in male circulatory migration and the out-migration of married women to examine its socio-cultural meaning.

It is true that there has been a remarkable influx of Iban males who work away from home since the late 1960s, when timber and oil industries in Sarawak showed a rapid growth. But as Kedit (1993) pointed out, for Iban males to leave the long-house temporarily was a culturally institutionalized custom that was reinforced by the females' subsistence activities in the village based on the long-established division of labor between the sexes. In addition, the Iban society experienced the shift to the monetary economy with the introduction of rubber planting in the early twentieth century. In that sense, the increase in the number of males who work away from home did not shake the socio-economic structure of the village community. When we examine the rural changes in terms of migration studies, it is clear that what is more important is the recent phenomenon of female outmigration brought about by the diversification and stabilization of the males' employment 
situation. Considering the important roles of married women in the maintenance of the subsistence economy and social relationships in particular, the drift of such females should be noted as a substantial factor in the acceleration of the long-house community's degradation in terms of the weakened solidarity of the aging bilek-family, the stagnation of subsistence activities, and the malfunction in the inheritance of tradition.

The changes observed in this paper may be just an example of the indigenous societies in the interior of Sarawak, but at least in the Iban society in the low and middle reaches of the large rivers where it is comparatively easier to access urban areas, the above-mentioned changes can be commonly seen. However, the Iban are still behind the Chinese and the Malay in terms of their economic situation, and those who failed to find work or reached retirement age without taking up steadier residence in town return to the long-house to dispose of their free time. In other words, long-house community means "insurance" to the urban dwellers, and it can be paradoxically but safely said that, although the long-house community has been decaying, it still provides assurance of the Iban's affirmative urban life. In this sense, the long-house preserves the reason for its existence.

This paper has clarified a new trend of outmigration of the Iban and structural changes of the long-house community. Concerning the migration between urban and rural areas, it is also necessary to investigate the changing ethnic relations that surround the increasing urban Iban, and the political and economic influences of retired people in their long-house community. These issues will be further discussed in another paper.

\section{Acknowledgement}

I would like to express my gratitude to Prof. Dr. Hiroshi Ishihara, Kyoto University for beneficial suggestions. This research project was realized thanks to Dr. Voon Phin Keong, ex-Prof. of Universiti Malaya, Dr. Peter Kedit, ex-Director of Sarawak Museum, and Dr. Daniel Chew, senior research fellow of Sarawak Development Institute. Thanks are also due to Datin Francisca Sadai binti Udang, who helped me by pro- viding support, accommodation, and information on the study area. This study was financially supported by the Grant-in-Aid for Scientific Research from the Ministry of Education, Science, Sports and Culture of Japan (No.07041024, headed by Prof. Yoshimi Komoguchi of Komazawa University). I owe endless gratitude to the late Prof. Yoshimi Komoguchi.

Editor's Note: This article was first published in Japanese in the Geographical Review of Japan 72A1 and won the AJG Award for 1999.

\section{Notes}

1. The author was given advice and assistance by the District Officer of Kanowit district in deciding on the study area.

2. In the town center of Kanowit, there were 13 store buildings in which about 100 shops were operating. Other than permanent stores, there was a public marketplace for perishables at the portside that opened every morning. Most of the permanent stores were owned by the Chinese, but stalls in the marketplace were operated by various people such as the Chinese, Iban, Malay, Indonesian, and Pakistani.

3. Previously, long-houses were widely distributed in Southeast Asia. For additional information on the types of long-houses or communal houses and their distribution in Southeast Asia, refer to Sugimoto (1971) and Waterson (1990). Concerning the social structure of the longhouse community, Loeb and Broek (1947) and Sekine (1979) are informative.

4. Because the Iban language and its pronunciation has regional differences, the rules of spelling are still inconsistent even among scholars. This paper, considering the previous studies on Iban society, follows the orthography of Kedit (1993).

5. The Iban vocabulary has no word equivalent to "family." Therefore, strictly speaking, to adopt the word "bilek-family" is questionable. But those who live together in a bilek are recognized as a managing unit of swidden agriculture and this unit is referred to as a se-bilek, with the prefix "se-" meaning "one." In this sense, se-bilek corresponds virtually to a stem family. This paper, following the previous studies, calls such unit the bilek-family.

6. The Catholic Church of Kanowit was established in 1883 as the first base along the Rajang Basin (Rooney 1981). This church not only introduced wet paddy, rubber, coffee, and pepper cultivation, but also founded schools and hospitals that had a considerable influence on the social change in this area.

7. Though the Iban's long-house community composition is mostly consanguineous, a bilek- 
family is thoroughly free in principal to break away from their long-house community and join another. Therefore, it is no wonder that some long-house communities include bilekfamilies that have no consanguine relationship. The long-house community of Rantau Kemiding Village was established based not only on consanguine relations, but also religious and local bonds.

8. Concerning the maturity of the community, it should be noted that in this period Rantau Kemiding Village produced several influential leaders, such as the minister of Land and Resources of the Sarawak Government, the District Officer of the Kanowit district, and the penghulu (chief of a certain domain). Due to the strong leadership of these people, the community achieved solidarity between the late 1950 s and the 1970s.

9. According to an interview with an officer of the Kanowit district, many long-house communities split and regrouped in the 1980 s as a result of Iban-based political affairs.

10. According to Fidler (1973), most of the Chinese managers of general stores acted as brokers of rubber sheets and established a system of selling general goods on credit to the Iban, who were expected to earn money by producing rubber sheets. This caused the Iban to be economically subordinated to the Chinese. This economic relationship between the Chinese and the Iban continued with subsequent generations and can be considered one of the factors that prevented the Iban from migrating to a new frontier.

11. Hong (1987) pointed out that one of the factors that encouraged the Iban to settle down was the government's frequent revision of land laws for the purpose of prohibiting the opening of virgin forests and restricting the migration of the indigenous peoples. In addition, the author assumes that the concept of exclusive land ownership among the Iban evolved from planting rubber on fallowed land and that the increase in land value contributed to the restriction of the long-house community's migration. This matter will be discussed in another paper.

12. One of the notable examples is the establishment of the Kanowit Rural Improvement School (1948-1957), which provided the Iban adults with instruction for the improvement of agricultural technologies (Annual report of district officer, Kanowit. Sarawak Gazette May 31, 1952: 103).

13. In those days the Iban used to shift even the wet paddy fields almost every year.

14. The Iban vocabulary for job or occupation is closely tied to words concerning migration.
Kedit (1993) explains such words as follows in relation to the Iban's migration; bejalai is to go on journeys with the view of acquiring wealth, material goods and social prestige, and bekuli is to do wage-laboring or to take on labor migration, while kerja is to work as non-manual wage-earner.

15. For example, Freeman (1970: 224-225) reported that in an Iban community of the Balleh region all of the unmarried males between 16 and 30 years old (15 persons) and $75 \%$ of the married males under 40 years old (16 persons) engaged in bejalai for three to six months during his research period in 1949 and 1950. He also calculated, with the data obtained in surrounding long-house communities, that about $20 \%$ of adult males are absent from the longhouse throughout the year.

16. This word is thought to derive from the Malay word "kerja."

17. In this paper, the author considers the heads of each bilek-family and their children to be of Rantau Kemiding origin regardless of their current place of residence. For the occupation data, the author counts those persons 15 years old and above. Because it was difficult to interview the stay-outs, the data on occupation was obtained mainly through interviews with those who stayed in the village, but the author tried to confirm this information as much as possible. Some stay-outs were visited at their current residences in town and some were interviewed when they returned temporarily to the long-house.

18. In this paper, those females who engage in "ngibun rumah" (to take care of domestic affairs) are classified as "housewife."

19. There is a very rough preconception that the Malay and Melanau are in power, the Chinese control the economy, and the Iban supply manual labor.

20. There is no clear criterion to judge whether an urban dweller is still considered a long-house member or not. Those who move out to another long-house to marry are regarded as nonmembers of their original community, though in some cases they return to the original bilek with their spouse. As will be mentioned, there are several vacant bileks in Rantau Kemiding, which are not necessarily abandoned. In principle, when a bilek-family leaves the long-house to join another community, the family forfeits their various rights in the original long-house. However, regarding the vacant bileks in Rantau Kemiding, the bilek owners who currently reside in urban areas are expected to return to the long-house in the near future. They also retain their rights as community members.

21. This number cannot be thought uncommon in 
urban areas. For example, according to the Sarawak population report, Sarawak 1991, the urban population of the Iban is 42,982 males and 42,680 females, and among them, those who are employed (between 15 to 64 years old) number 22,385 males (52\%) and 8,344 females (20\%). This illustrates the relatively low rate of female employment.

22. Most urban centers in Sarawak are export centers for a specific product in the earlier stage of its development; Sibu was an export port for timber products, Miri was the base for a developing oil field, and Bintulu was a producing center of natural gas. Recently, these towns have also begun to compete with the raw material processing industries and the tourist industries by capitalizing on the natural environment and cultural experience.

23. Many Ibans mention the educational disparities between the urban and rural areas. They are also acutely conscious of the effects of educational background on job opportunity and wage level. For example, Chinese schools, which are rarely found in rural areas, attract considerable attention from the Iban because of their higher educational level. Thus, some parents of Rantau Kemiding origin send their children to Chinese schools for better future opportunities.

24. Though there are regional and annual differences, the agricultural cycle of planting dry paddy can be roughly summarized as follows: felling trees and mowing underbrush in July, burning in August, seeding in September and early in October, and harvesting in February and March. On the other hand, the cycle of wet paddy is a little different: mowing and weeding in July, burning in August, making a rice nursery late in August and early in September, transplanting in October, and harvesting in February and March. In both cases, the Iban weed a few times by December and sometimes spray insecticide.

25. The Iban tend to plant many kinds of paddy in a small piece of land. Even in wet paddy fields, they try to plant dry paddy on a small convex ground. In Table 6, such insignificant amounts of planted paddy are indicated as "mit" (a little), which is excluded from the total sum for the sake of convenience.

26. Out of 39 kinds of paddy, 12 kinds were adaptable to both wet and dry fields.

27. Each bilek-family is supposed to have a few kinds of supplementary sacred rice, called padi sangking, other than the padi pun. This supplementary sacred rice also has a symbolic meaning in the succession of the bilek. Freeman (1970: 50-51) assumes that it is possible to trace the family line by retracing the padi pun and padi sangking.

28. One person asserted that, for those who had converted to Christianity, the sacred rice no longer has an important meaning.

29. Bilek and ruai are regarded as having contrasting functions, which is related to the pattern of dichotomy generally found in Iban society. Concerning dichotomy in Iban society, refer to Uchibori (1991).

30. Because the Malaysian Government has an agelimit system for the retirement of government servants ( 55 years old), in this paper, those who are 55 years old and above are regarded as old people.

31. Old people find it comfortable to kill time in the ruai where they can easily find someone to talk to. Therefore, even though they are encouraged to live with their children in urban areas, they rarely accept their children's invitations.

32. Refer to note 10 and note 11 .

\section{References}

Ahmad, M. A., and Noran, F. Y. 1991. Development and change in Batang Ai, Sarawak. Sarawak Museum Journal 63: 267-282.

Armstrong, W., and McGee, T. G. 1985. Theatres of accumulation: Studies in Asian and Latin American urbanization. London: Methuen.

Cleary, M., and Eaton, P. 1995. Borneo: Change and development. Kuala Lumpur: Oxford University Press.

Cramb, R. A., and Wills, I. R. 1990. The role of traditional institutions in rural development. World Development 18: 347-360.

Danaraj, N. 1995. Challenges, options and prospects for higher value-added industrialization for Sarawak: Beyond primary processing. In Sarawak: The next step, ed. H. Solhee, B. J. Bujang, and S. A. Hua, 27-56. Kuching: Heng Sing Brothers Press.

Fawcett, J. T., Khoo, S.-E., and Smith, P. C. eds. 1984. Women in the cities of Asia: Migration and urban adaptation. Boulder: Westview Press.

Fidler, R. V. 1973. Kanowit: An overseas Chinese community in Borneo. Ph.D. dissertation, University of Pennsylvania.

Freeman, J. D. 1955. Iban agriculture. London: Her Majesty's Stationery Office.

Freeman, J. D. 1970. Report on the Iban. London: The Anthlone Press.

Freeman, J. D. 1981. Some reflections on the nature of Iban society. An Occasional Paper of the Department of Anthropology, Research School of Pacific Studies, The Australian National University.

Harbison, S. F. 1981. Family structure and family strategy in migration decision making. In Migration decision making, ed. G. F. De Jong and R. W. Gardner, 225-251. New York: Pergamon Press.

Hong, E. 1987. Natives of Sarawak: Survival in Bor- 
neo's vanishing forest. Penang: Institut Masyarakat.

Hugo, G. 1992. Migration and rural-urban linkages in the ESCAP region. In Migration and urbanization in Asia and the Pacific, ed. Economic and Social Commission for Asia and the Pacific, 91-117. New York: United Nations.

Kedit, P. M. 1980. Modernization among the Iban of Sarawak. Kuala Lumpur: Dewan Bahasa dan Pustaka.

Kedit, P. M. 1993. Iban bejalai. Kuala Lumpur: Ampang Press.

Loeb, E. M., and Broek, J. O. M. 1947. Social organization and the longhouse in Southeast Asia. American Anthropologist 49: 414-425.

Morrison, P. 1993. Transition in rural Sarawak. $P a$ cific Viewpoint 34-1: 45-68.

Padoch, C. 1982. Migration and its alternatives among the Iban of Sarawak. Hague: The Hague-Martinus Nijhoff.

Pringle, R. 1970. Rajahs and rebels: The Iban of Sarawak under Brooke rule, 1841-1941. London: Macmillan.

Prothero, R. M., and Chapman, M. 1985. Circulation in Third World countries. London: Routledge \& Kegan Paul.

Rooney, J. 1981. Khabar gembira: A history of the catholic church in East Malaysia and Brunei, 1880-1976. London: Tien Wah Press.

Root, B. D., and de Jong, G. F. 1991. Family migration in a developing country. Population Studies 45: 221-233.

Sarawak, State Government of. 1997. Internal migration study, Sarawak. Kuching: State Government of Sarawak.

Sekine, Y. 1979. Ronguhausu wo meguru kuukann kouzou. Kikan Jinruigaku 10-2: 54-107. (J)

Smith, P.C., Khoo, S.-E., and Go, S.P. 1984. The migration of women to cities: A comparative per- spective. In Women in the cities of Asia, ed. J. T. Fawcett, S.-E. Khoo, and P. C. Smith, 15-35. Boulder: Westview Press.

Sugimoto, N. 1971. Tonan Ajia no juukyo. Kikan Jinruigaku 2-3: 147-191. (J)

Sutlive, V.H. 1972. From longhouse to pasar. Ph.D. dissertation, The University of Pittsburgh.

Sutlive, V. H. 1991. Keling and Kumang in town. In Female and male in Borneo, ed. V. H. Sutlive, 489 -515. Williamsburg: Borneo Research Council, Inc.

Sutlive, V.H. 1992. The Iban of Borneo. Kuala Lumpur: S. Abdul Majeed \& Co.

Sutlive, V. H., and Appell, G. N. 1991. Introduction. In Female and male in Borneo, ed. V.H. Sutlive, xi-xlvi. Williamsburg: Borneo Research Council, Inc.

Thadani, V. N., and Torado, M. P. 1984. Female migration: A conceptual framework. In Women in the cities of Asia, ed. J. T. Fawcett, S.-E. Khoo, and P. C. Smith, 36-59. Boulder: Westview Press.

Tsubouchi, Y. 1993. Noson no henka to muhenka. In Chiiki kenkyu to hatten no ronri, ed. T. Yano, 93116. Tokyo: Kobundo. (J)

Uchibori, M. 1991. Sakashima no sekai. In Tonan Ajia no sekai, ed. N. Maeda, 170-191. Tokyo: Kobundo. (J)

Uchibori, M. 1996. Mori no tabekata. Tokyo: The University of Tokyo Press. (J)

Waterson, R. 1990. The living house. Singapore: Oxford University Press.

Williams, L. B. 1989. Postnuptial migration and the status of women in Indonesia. Journal of Marriage and the Family 51: 895-905.

Wright, L., Morrison, H., and Wong, K. F. 1972. Vanishing world: The Ibans of Borneo. New York: Weatherhill/Serasia.

$(\mathrm{J})$ : written in Japanese 